Gut, 1972, 13, 713-717

\title{
Salivary secretion in duodenal ulcer disease ${ }^{1}$
}

\author{
ANDRÉ L. BLUM with the technical assistance of JOEL W. WOODALL \\ From the Division of Gastroenterology, Department of Medicine, University of Alabama in Birmingham \\ School of Medicine, and Veterans Administration Hospital, Birmingham, Alabama
}

SUMMARY Salivary response to stimulation with citric acid was higher in patients with duodenal ulcer disease than in patients with other diseases of the upper gastrointestinal tract. This increase was proportional to an increase of histamine-stimulated gastric acid secretion. In duodenal ulcer disease, the increase in parietal cell mass may therefore be associated with the growth of other exocrine organs such as the salivary glands.

The only consistent and persisting changes in duodenal ulcer disease, apart from the ulcer and its scar, are thought to be an enlargement of the parietal cell mass and an increase in gastric secretion (Grossman, 1960). In the present study it is shown that in ulcer patients the secretion rate of the salivary glands is increased in proportion to the rate of gastric acid secretion. It is suggested that duodenal ulcer disease is characterized by an enlargement of several exocrine glands, such as the parietal cell system, salivary glands, and pancreas while only the enlargement of one gland-the stomach-is related to ulcer symptoms.

\section{Material and Methods}

\section{PATIENTS}

Seventy hospitalized male veterans who were scheduled for gastric analysis in 1969 and 1970 fulfilled the following criteria: (1) A barium meal had been interpreted independently by two examiners. (2) A disease of the upper gastrointestinal tract was the only major pathological finding at the time of study. Specifically excluded from this study were patients with complications of ulcer disease, such as bleeding and obstruction. (3) No gastric surgery had been performed except in three patients who had previously undergone simple suture for perforated duodenal ulcer. For at least one week before secretion tests the patients had not received anti-

${ }^{1}$ This work was supported by research funds of the Veterans Administration Hospital in Birmingham, NIH grants 2A-5286 and AM 09260 and NSF grant GB8351.

Please address correspondence to: André L. Blum, M.D. Med. Klinik Stadtspital Triemli 8055 Zurich/Switzerland.

Received for publication 27 June 1972. cholinergics and other drugs which might have a lasting effect on gastric or salivary secretion.

Patients with duodenal ulcer disease, including four in whom ulcer was inactive at the time of admission, formed the duodenal ulcer group. All other patients formed the control group. In patients with gastric ulcer and gastric cancer diagnosis was confirmed by gastroscopy and/or surgery at a later date. Patients with gastrooesophageal reflux had heartburn, reflux of barium following a barium meal, and abnormal histology in an oesophageal biopsy.

In patients with functional disorders, at least two barium meals were performed. Small sliding hiatal hernias were seen in four patients. No abnormal findings were seen in five patients. In all nine patients, epigastric discomfort was nonspecific, and a cholecystogram, a barium enema, and oesophageal histology were normal.

\section{PROCEDURES}

Tests were performed eight $\pm 1 \cdot 3$ days (mean \pm SEM) after hospital admission in duodenal ulcer patients and eight \pm 1.5 days after admission in control patients respectively. Salivary secretion tests were started at 8.00 am after a 12-hour fast and were followed by gastric secretion tests.

\section{Salivary secretion}

For mechanical stimulation the subject was asked to exercise the muscles of the cheek and tongue against the teeth and squeeze the saliva out before voiding it into a preweighed beaker. The process was continued for 10 minutes at the end of which the bottle was weighed again and salivary flow calculated by difference.

For chemical stimulation the subject emptied from the mouth all salivary remnants. At zero time, 
$0.3 \mathrm{ml}$ of citric acid solution was delivered on the anterior surface of the tongue and tasted by rolling movements of the tongue. At the 30th second, $5 \mathrm{ml}$ of distilled water was delivered rapidly below the tongue. Between the 45th and 60th seconds the patient forcefully emptied the contents of the mouth into a preweighed beaker. The test was performed three times at three to four minute intervals. Salivary flow was calculated by subtracting $5 \cdot 3 \mathrm{~g}$ from the increase in beaker weight.

The response to chemical stimulation was obtained by subtracting from the observed flow rate due to chemical stimulation the flow rate due to mechanical stimulation.

Further details of collection techniques have been reported in previous studies (Blum and Makhlouf, 1971; Makhlouf and Blum, 1971).

\section{Gastric secretion}

A $14 \mathrm{Fr}$ radioopaque nasogastric tube was positioned in the antrum under fluoroscopic control. During the test the patient was recumbent, usually on his left side. Fasting juice was aspirated manually with a syringe. For further collections, suction pulses of 40 to $45 \mathrm{~mm} \mathrm{Hg}$ were applied by a modified Gomco intermittent suction apparatus. Every five minutes, patency of the tube was checked by injecting $5 \mathrm{ml}$ of air. Basal secretion was collected for 60 minutes. At the 30th minute, $20 \mathrm{mg}$ of Benadryl (Parke Davis \& Co) was injected into the deltoid muscle. At the 60th minute, histamine phosphate (Lilly) was injected subcutaneously at a dose of $40 \mu \mathrm{g} / \mathrm{kg}$ body weight. Stimulated secretion was collected for 60 minutes. During the entire test cotton rolls were inserted into the sulci of the cheeks and under the tongue in order to prevent contamination of gastric juice by saliva. In each 15-minute sample acidity was measured by titration with $0.1 \mathrm{~N} \mathrm{NaOH}$ to $p \mathrm{H} 7$ in an automatic titrator (Radiometer, Copenhagen). Unstimulated and stimulated acid output were calculated by adding 15-minute outputs during the pre- and post-histamine hour respectively.

\section{Results}

Characteristics such as age, body weight, and race, duration and type of subjective symptoms were similarly distributed among the two groups (Tables I and II). On palpation, the salivary gland area did not show abnormal findings in any patient.

In the first consecutive 25 subjects of this study (11 duodenal ulcer patients and 14 control subjects respectively) dose response curves were constructed by using the following concentrations of citric acid: $2.5 \%, 5 \%, 7.5 \%, 10 \%$, and $20 \%$. The response to $10 \%$ citric acid was a constant fraction of the

\begin{tabular}{|c|c|c|c|}
\hline Characteristics & $\begin{array}{l}\text { Duodenal } \\
\text { Ulcer Group } \\
(38)\end{array}$ & $\begin{array}{l}\text { Control } \\
\text { Group } \\
(32)\end{array}$ & $\begin{array}{l}\text { P Value } \\
-\end{array}$ \\
\hline $\begin{array}{l}\text { Age }(\mathrm{yr}, \text { mean } \pm \text { SEM) } \\
\text { Body weight }(\mathbf{k g} \text {, mean } \pm \text { SEM) } \\
\text { Race-Negroes }\end{array}$ & $\begin{array}{l}49 \cdot 2 \pm 2 \cdot 0 \\
69 \cdot 2 \pm 1 \cdot 4 \\
10(26 \%)\end{array}$ & $\begin{array}{l}50 \cdot 0 \pm 2 \cdot 1 \\
66 \cdot 9 \pm 2 \cdot 1 \\
6 \quad(19 \%)\end{array}$ & $\begin{array}{l}>0.05 \\
>0.05 \\
>0.05\end{array}$ \\
\hline $\begin{array}{l}\text { White collar workers } \\
\text { Duodenal ulcer } \\
\text { Gastric ulcer } \\
\text { Gastrooesophageal reflux } \\
\text { Gastric cancer } \\
\text { Functional disorder }\end{array}$ & $\begin{array}{rr}6 & (16 \%) \\
38 & (100 \%) \\
7 & (11 \%) \\
5 & (5 \%) \\
0 & \end{array}$ & $\begin{array}{rr}4 & (13 \%) \\
0 & \\
14 & (44 \%) \\
8 & (25 \%) \\
1 & (3 \%) \\
9 & (28 \%)\end{array}$ & $>0.05$ \\
\hline
\end{tabular}

Table I Characteristics of patients

${ }^{1}$ Nos. of patients in brackets.

\begin{tabular}{|c|c|c|c|}
\hline Symptom & $\begin{array}{l}\text { Duodenal } \\
\text { Ulcer Group }\end{array}$ & $\begin{array}{l}\text { Control } \\
\text { Group }\end{array}$ & P Value \\
\hline $\begin{array}{l}\text { Past History } \\
\text { Duration of symptoms } \\
\text { (years, mean } \pm \text { SEM) } \\
\text { Pain }{ }^{1}(n) \\
\text { Water brash (n) } \\
\text { Dry mouth (n) }\end{array}$ & $\begin{array}{r}10 \cdot 4 \pm 1 \cdot 7 \\
38(100 \%) \\
8(21 \%) \\
3 \quad(8 \%)\end{array}$ & $\begin{array}{r}7 \cdot 2 \pm 2 \cdot 3 \\
32(100 \%) \\
6(19 \%) \\
4(13 \%)\end{array}$ & $\begin{array}{l}>0.05 \\
>0.05 \\
>0.05 \\
>0.05\end{array}$ \\
\hline $\begin{array}{c}\text { On Admission } \\
\operatorname{Pain}^{1}(\mathrm{n})\end{array}$ & $34(90 \%)$ & $31(97 \%)$ & $>0.05$ \\
\hline $\begin{array}{l}\text { Day of Study } \\
\text { Pain (n) } \\
\text { Water brash (n) } \\
\text { Dry mouth (n) }\end{array}$ & $\begin{array}{lr}2 & (5 \%) \\
0 & (0 \%) \\
5 & (13 \%)\end{array}$ & $\begin{array}{lr}4 & (13 \%) \\
0 & (0 \%) \\
5 & (16 \%)\end{array}$ & $\begin{array}{l}>0.05 \\
>0.05 \\
>0.05\end{array}$ \\
\hline
\end{tabular}

Table II Subjective symptoms

${ }^{1}$ Epigastric pain and/or heartburn; 'after $\geqslant 12 \mathrm{hr}$ fasting; $n=$ number of patients.

calculated maximal secretion rate $(64 \pm 2 \%$ in duodenal ulcer patients and $63 \pm 2 \%$ in control subjects respectively, mean \pm SEM). These observations corresponded to values previously obtained in young healthy volunteers (Makhlouf and Blum, 1971). In subsequent patients, therefore, the response to $10 \%$ citric acid was used as an estimate for the secretory capacity of the salivary glands.

Of the three consecutive salivary secretion tests with $10 \%$ citric acid, the response in the second and in the third test was $101 \pm 0.6 \%$ and $99 \pm 0.6 \%$ (mean \pm SEM) of the first response respectively. This good reproducibility corresponds to observations in previous studies (Blum and Makhlouf, 1971; Makhlouf, 1971).

Results of secretion tests are summarized in Table III. Salivary secretion in response to citric acid

\begin{tabular}{lcc}
\hline Type of Secretion & Duodenal Ulcer Group & Control Group \\
\hline Gastric (m-equiv/hr) & $27 \cdot 7 \pm 1 \cdot 7$ & $19.6 \pm 2.2$ \\
Salivary (ml/min) & $5 \cdot 36 \pm 0.32$ & $4.00 \pm 0.34$ \\
\hline
\end{tabular}

Table III Results of secretion tests ${ }^{1}$

${ }^{1}$ Data are given as mean \pm SEM. Differences between duodenal ulcer group and control group are significant at 0.01 level. 


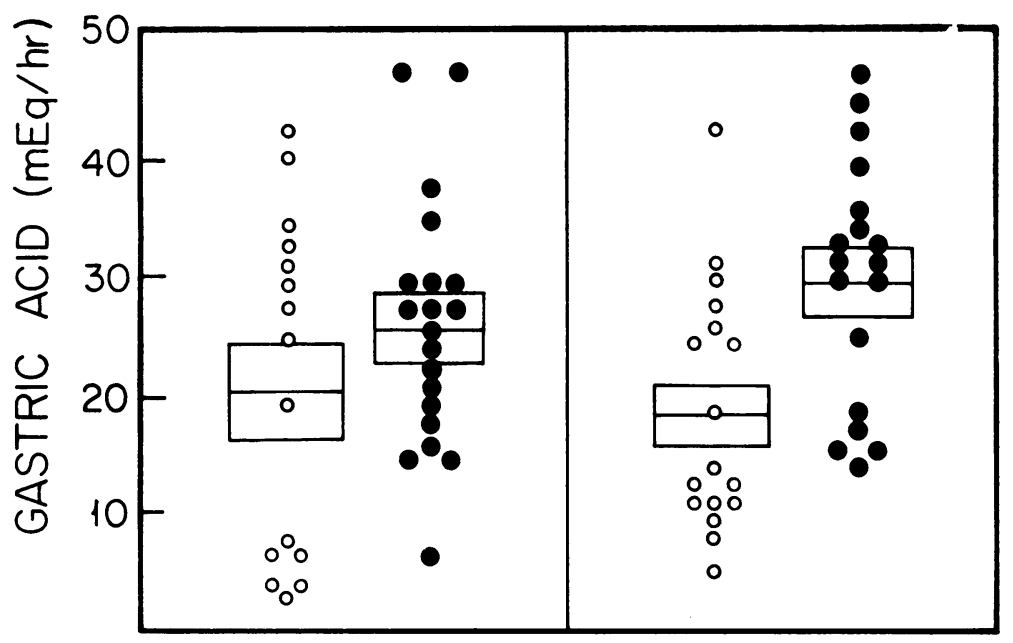

Fig. 1 Gastric acid output during histamine stimulation (upper graph) and salivary output during stimulation with citric acid (lower graph). Results for patients below and above 50 years of age are given on left and right side of each graph respectively. Closed symbols represent patients of duodenal ulcer group and open symbols represent patients of control group. A small divided box indicates mean $\pm S E M$.

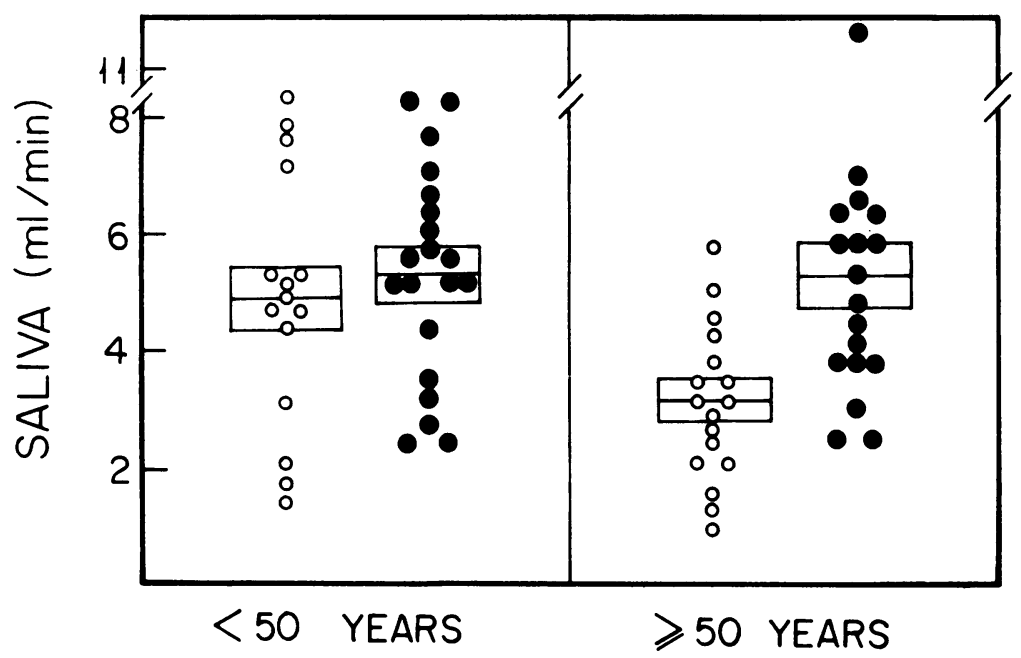

in patients with duodenal ulcer was $34 \%$ higher than in controls, and gastric acid output in response to histamine was $41 \%$ higher.

The effect of age on secretion rate is shown in
Figures 1 and 2. A reduction of salivary secretion with old age was seen in controls, but not in patients with duodenal ulcer. In an analysis of covariance, both age and duodenal ulcer were significantly

\begin{tabular}{|c|c|c|c|c|}
\hline \multirow[t]{2}{*}{ Characteristics } & \multicolumn{4}{|c|}{ Rate of Salivary Secretion (ml/min) } \\
\hline & \multicolumn{2}{|l|}{ Duodenal Ulcer Group } & \multicolumn{2}{|l|}{ Control Group } \\
\hline $\begin{array}{l}\text { All patients } \\
\text { Smoking } \\
\text { Drinking } \\
\text { Dentures } \\
\text { Gastric ulcer } \\
\text { Gastrooesophageal reflux }\end{array}$ & $\begin{array}{l}5.40 \pm 0.40(n=20) \\
5.38 \pm 0.41(n=15) \\
5.45 \pm 0.38(n=7) \\
5.01 \pm 0.65(n=6) \\
5.61 \pm 0.72(n=5) \\
6.72(n=1)\end{array}$ & $\begin{array}{l}5.31 \pm 0.51(n=18) \\
5.21 \pm 0.59(n=11) \\
4.89 \pm 0.65(n=5) \\
5.40 \pm 0.61(n=10) \\
5.60(n=2) \\
5.80(n=1)\end{array}$ & $\begin{array}{l}4.95 \pm 0.55(n=15) \\
4.73 \pm 0.55(n=14) \\
4.82 \pm 0.59(n=9) \\
5.37 \pm 1.47(n=4) \\
5.11 \pm 0.69(n=5) \\
5.30(n=2)\end{array}$ & $\begin{array}{l}3 \cdot 17 \pm 0.32(n=17) \\
3.33 \pm 0.31(n=13) \\
3 \cdot 25 \pm 0.29(n=10) \\
2.91 \pm 0.40(n=11) \\
3 \cdot 13 \pm 0.40(n=9) \\
3.27 \pm 0.59(n=6)\end{array}$ \\
\hline
\end{tabular}

Table IV Rate of stimulated salivary secretion ${ }^{1}$

${ }^{1}$ mean \pm SEM, $\mathbf{n}=$ number of patients. 


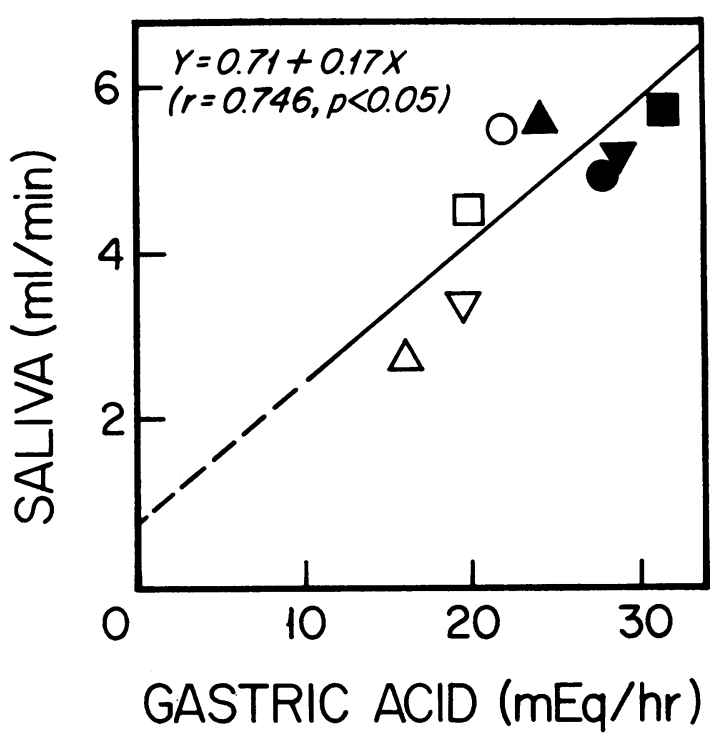

Fig. 2 Linear relation between salivary secretion $(y)$ and gastric secretion $(x)$. Each symbol represents the mean of a 10-year age group: 30-39 years $(O, 0), 40-49$ ( $\square \square$ ), $50-59(\nabla \nabla)$, and $\geqslant 60(\triangle \Delta)$. Closed symbols represent patients with duodenal ulcer and open symbols represent patients of control group.

(P $<0.01)$ correlated with rate of salivary secretion. Thus, the difference between duodenal ulcer and control group was most marked in old age. A similar tendency was seen for gastric secretion. In Fig. 2, rate of stimulated salivary secretion in each 10-year age group is plotted against the rate of stimulated gastric secretion. A linear regression could be fitted to these data. On the average, therefore, salivary secretion rate changed in proportion to gastric secretion rate.

Other factors which might have an effect on salivary secretion are listed in Table IV. They include local irritants such as dentures, smoking (one or more cigarettes per day), and drinking (two or more cocktails per week), and diagnosis such as gastric ulcer and gastrooesophageal reflux. Salivary and gastric secretion of patients with these characteristics were similar to the rates of age-matched patients without these findings.

\section{Discussion}

The results of the present study demonstrate that patients with duodenal ulcer disease have a higher rate of salivary secretion than matched control patients without duodenal ulcer. This difference in secretion rate is not due to habits such as smoking and drinking or to other factors such as wearing of dentures but it appears to be related to the rate of gastric acid secretion. It could be shown that in duodenal ulcer disease the rate of salivary secretion was increased in proportion to the rate of gastric secretion. Furthermore, the fall in secretion rate of exocrine glands which usually occurs beyond the age of 50 (Garrett, 1962; Baron, 1963a and b; Waterhouse, 1963; Blackman, Lambert, and Thayer, 1970) was not observed in patients with duodenal ulcer. The rate of both gastric and salivary secretion remained high in older ulcer patients. This observation confirms previous studies on this subject (Baron, 1963b; Blackman et al, 1970). It is well established that the rate of gastric secretion is related to the parietal cell mass and that both gland size and secretion rate depend upon body weight (Boyd, 1941; Brody, 1945; Card and Marks, 1960; Crean, 1967; 1969; Blackman et al, 1970). In duodenal ulcer disease, an increase in gastric secretion is caused by an increase in parietal cell mass. It is likely therefore that the parallel increase in salivary secretion is caused by an increase in salivary gland mass. This postulate is supported by our previous observation of a relationship between salivary secretion and body weight (Blum and Makhlouf, 1971) and by the well estab. lished relationship between salivary gland size and body weight (Boyd, 1941). In this context it is interesting to note that pancreatic secretion is also increased in duodenal ulcer disease (Petersen, 1970). It may well be that duodenal ulcer disease is characterized by an enlargement of several exocrine glands such as the parietal cell system, salivary glands, and pancreas while only the enlargement of one glandthe stomach-is related to ulcer symptoms.

Increased salivary secretion in patients with duodenal ulcer might be of some practical importance. The value of gastric secretion tests for the diagnosis of duodenal ulcer disease is low since there is a broad overlap of secretion rates between duodenal ulcer and control populations (Baron, 1963a and b; Blackman et al, 1970). The results of the present study suggest that combined tests of gastric and salivary secretion might improve diagnostic accuracy-at minimal additional costs of time and discomfort.

\section{References}

Baron, J. H. (1963). Studies of basal and peak acid output with augmented histamine test. Gut, 4, 136-144.

Baron, J. H. (1963). An assessment of the augmented histamine test in the diagnosis of peptic ulcer. Gut, 4, 243-253.

Blackman, A. H., Lambert, D. L., Thayer, W. R., and Martin, H. F. (1970). Computed normal values for peak acid output based on age, sex and body-weight. Amer. J. dig. Dis., 15, 783-789.

Blum, A. L., and Makhlouf, G. M. (1971). Determinants of salivary response to mechanical stimulation. Gut, 12, 650-653. 
Boyd, E. (1941). Outline of Physical Growth and Development. Burgess, Minneapolis.

Brody, S. (1945) In Bioenergetics and Growth, p. 628. Reinhold, New York.

Card, W. I., and Marks, I. N. (1960). The relationship between acid output of the stomach following 'maximal' histamine stimulation and the parietal cell mass. Clin. Sci., 19, 147-163.

Crean, G. P. (1967). In Gastric Secretion, Mechanisms and Control, edited by T. K. Shritka, J. A. L. Gilbert, R. C. Harrison, Pergamon, Oxford. p. 33.

Crean, G. P. (1969). In Non-Insulin-Producing Tumours of the Pancreas, p. 141. Thieme, Stuttgart.

Garrett, J. R. (1962). Some observations on human submandibular salivary glands. Proc. roy. Soc. Med., 55, 488-491.
Grossman, M. I. (1960). The pathologic physiology of peptic ulcer. Amer. J. Med., 29, 748-753.

Grossman, M. I. (1960). The pathologic physiology of peptic ulcer. Amer. J. Med., 29, 748-753.

Makhlouf, G. M., and Blum, A. L. (1971). Salivary expression of the taste response to chemical stimulation. Scand. J. Gastroent., 6, 523-526.

Petersen, H. (1970). Relationship between gastric and pancreatic secretion in patients with duodenal ulcer. Scand. J. Gastroent., $5,321-326$.

Waterhouse, J. P. (1963). Focal adenitis in salivary and lacrimal glands. Proc. roy. Soc. Med., 56, 91 1-918.

\section{The August 1972 Issue}

\section{THE AUGUST 1972 ISSUE CONTAINS THE FOLLOWING PAPERS}

Nodular lymphoid hyperplasia with hypogammaglobulinaemia A. B. AJDUKIEWICZ, G. R. YOUNGS, AND I. A. D. BOUCHIER

The effects of different bile salts on the absorption of fluid, electrolytes, and monosaccharides in the small intestine of the rat in vivo J. T. HARRIES AND G. E. SLADEN

Congenital dilatation of the intrahepatic bile ducts associated with the development of amyloidosis J. FEVERY, W. TANGHE, R. KERREMANS, V. DESMET, AND J. DE GROOTE

Chronic hepatitis and cirrhosis of the liver in cryoglobulinaemia G. P. JORI AND G. BUONANNO

Impaired lymphocyte reactivity against tumour cells in patients with Crohn's disease B. P. MACLAURIN, W. T. COOKE, AND N. R. LING

\section{Ectopic Enterobius vermicularis G. S. A. MCDONALD} AND D. O'B. HOURIHANE

Three cases of spontaneous duodeno-colic fistula BRUCE TORRANCE AND COLIN JONES
Aspirin ingestion and perforated peptic ulcer J. M. DUGGAN

Blood loss after partial gastrectomy J. MCLEAN BAIRD AND D. R. SUTTON

The Zollinger-Ellison syndrome due to an infiltrating tumour of the stomach C. M. S. ROYSTON, D. ST. J. BREW, J. R. GARNHAM, B. H. STAGG, AND JULIA POLAK

Interaction of calcium and pentagastrin on gastric acid secretion in man J. CHRISTIANSEN AND $L$. HENDEL

Tuberculous ileo-colitis in Ibadan: a clinico-radiological review E. A. LEWIS AND T. M. KOLAWOLE

Excitatory effects of adrenaline upon isolated preparations of human colon D. J. GAGNON, G. DEVROEDE, AND S. BELISLE

Progress report Smoking and the gastrointestinal tract JOHN R. BENNETT

Progress report The structure and function of gastric mucus A. ALLEN AND D. SNARY

Notes and activities

Copies are still available and may be obtained from the PUBLISHING MANAGER,

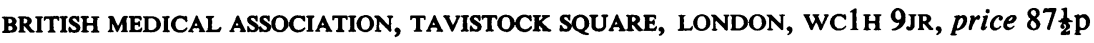

